\title{
Some thoughts on Tungusic ethnolinguistics
}

Michael KNÜPPEL: Sprachtabus in We should trace the basis of this tungusischen Sprachen und Dia- work to the Nachlaß of the late lekten. Am Beispiel von S. M. Ši- professor Gerhard Doerfer (1920rokogorovs "Tungus Dictionary". 2003), a well-known figure among Tunguso-Sibirica, Band 33. Wies- specialists of Tungusic languages baden: Harrassowitz 2012. 131 pp. and cultures. Similar precedents 
characterize the publication of various volumes, some of which have already appeared in the TungusoSibirica series (e.g. Band 31.I-II: Gerhard Doerfer, 2011, Lamutische Märchen und Erzählungen. Teil I: Kategorisierte Märchen und Erzählungen. Teil II: Nicht-kategorisierte Märchen und Erzählungen). As a matter of fact, this work grows out of the linguistic materials collected, in the form of notes, by Gerhard Doerfer during the drawing-up of his Etymologisch-Ethnologisches Wörterbuch tungusischer Dialekte (posthumously published, with the collaboration of Michael Knüppel $[=\mathrm{MK}]$, in 2004) and the theoretical formulations on taboo and language by $\mathrm{M}$. Crombach, among others. Unlike other cases in which G. Doerfer is fully acknowledged as the author, with the eventual (but crucial) participation of MK as editor, collaborator or even co-author, this time the original form of Doerfer's notes was such that a complete reworking was required, hence $\mathrm{MK}$ as the sole author.

The main goal of this book is to present the Tungusic words contained in the famous dictionary of the late Russian ethnologist S.M. Shirokogoroff (1889-1939), which bear witness to different taboo traits. Their etymological and comparative background is presented. The scholarly discussion of linguistic materials is contained in the second chapter (pp. 29-76), which is divided thematically into body parts, diseases, animals, misfortunes, shamanhood, cosmology, death and others. Each subsection deals with an individual concept, e. g. menstruation (pp. 28-29), smallpox (pp. 36-40), the tiger (pp. 54-56) or the echo (pp. 75-76), to mention just a few. Each subsection may contain between one and a dozen different, allegedly taboo terms. Chapters 3, 4 and 5 (pp. 77-90) cover the interpretation and classification of the words analyzed in chapter two, and the conclusions. The rest of the book is distributed as follows: table of contents (pp. 5-6); prologue (pp. 7-9); a reproduction verbatim of a fragment by Shirokogoroff on bears and taboo, originally published in 1935 and included here for illustrative purposes (for further remarks on this issue, see pp. 46-54); abbreviations (pp. 93-98); a very extensive bibliography (pp. 99-112); and the index verborum (pp. 113-131). The latter is organized according to languages; sometimes it can be difficult to locate a given item unless one knows beforehand that, for example, Kumare-Manegir are indexed sub Ewenki, and not sub Solon, etc.).

The problems surrounding the use of taboo in the domain of 
etymology have been extensively discussed in the specialist literature (MK presents a brief survey in pp. 11-20; I believe that the best piece on the topic remains Meillet's masterful article "Comment les mots changent de sens", first published in L'Année Sociologique 9, 1906, pp. 1-39, and later included in his Linguistique historique et linguistique générale, Paris / Genève 1982, pp. 230-271). It is enough to say that the field of Tungusic historical linguistics has not been immune to its dangers. The "justbecause-it-is-so" argument of the so-called "taboo conspiracy" (anything goes when taboo comes in) has been regrettably invoked more than once.

A recent instance of this practice involves Manchu helmeku helmehen 'spider' which is now linked to Common Tungusic *kömkä 'louse' (see materials in V. I. Cincius [ed.], Sravnitel'nij slovar' tunguso-man'čžurskix jazykov, 2 vols., Leningrad 1975-1977 [= SSMTJa] 1.430a. Note that Literary Udihe kumugä [> Amurian Udihe kumuä] has a secondary epenthetic vowel; unless otherwise stated, reconstructions come from G. Doerfer [unter Mitwirkung von Michael Knüppel], EtymologischEthnologisches Wörterbuch tungusischer Dialekte, Hildesheim / Zürich / New York 2004). Accord- ing to the authors of this proposal (S. Starostin / O. Mudrak / A. Dybo, Etymological Dictionary of the Altaic Languages, Leiden 2003, vol. 2, pp. 738-739), the intrusive $-l$ - in Manchu is secondary, with its origin traceable back to helme 'shadow' after contamination (see SSTMJa 2.481a, where both words have been subsumed under the same heading, i. e. 'shadow'). Unfortunately, the same authors do not comment on the fact that the resulting forms ${ }^{*}$ heme.ku ${ }^{* *}$ heme.hen (note that $-k u$ and -hen are derivative suffixes), i. e. the hypothetical forms previous to the insertion of the secondary $-l$-, still present serious discrepancies with CT ${ }^{\star}$ kömkä. Nor do they mention that the semantic association between 'shadow/darkness' and 'spider' is cross-linguistically very common, as spiders and many other insects dwell or look for shelter in the darkness of holes (cf. helmen

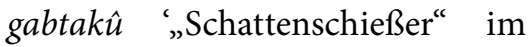
Yangtze und Huai lebendes, der Weichschildkröte ähnliches Reptil mit drei Füßen, das wenn menschliche Schattenbilder aufs Wasser fallen, nach den Menschen Sand spuckt, der schmerzhafte Entzündungen hervorruft', in E. Hauer, Handwörterbuch der Mandschusprache, Wiesbaden $2007^{2}$, p. 225b s.v. helmen, and O. Corff [ed.], Auf kaiserlichen Befehl erstelltes Wörterbuch des Manjurischen in 
fünf Sprachen, Wiesbaden 2013, vol. 2, p. 985 [4508-2]). Therefore, 'shadow' > 'spider' is a semantic specialization that does not require the involvement of a third word or taboo assumptions.

If something, one could claim that there is a strange relationship between Manchu helmen 'shadow' (isolated in Tungusic) and silmen 'shady, sunless' which could be very tentatively related to $\mathrm{CT}{ }^{*}$ simgön id. (see SSMTJa 2.87-88; this connection is deliberately ignored in J.A. Alonso de la Fuente, "Written Manchu talman 'mist"', Zentralasiatische Studien 41, 2012, pp. 107-135, see pp. 120-121). Now, one could speculate that ${ }^{\star *}$ hemeku (or even ${ }^{\star}$ hemen 'shadow'!) got its - $l$ - from silmen, or that the origin of the irregular developments accounting for the evolution silmen < * simgön (cf. Literary Nanay sinmu ${ }^{n}$ $<{ }^{*}$ simnön, with metathesis) should be sought in helmen. We could even bring *kulya+ 'beetle, worm; snake' (no Manchuric cognates, see SSTMJa 1.428 b, discussed by MK in p. 63) into the picture. Regardless of which option one prefers, there is no need to resort to the "taboo conspiracy", but rather to simply assume that the most common case of contamination, based on semantic and formal similarity, has taken place, as in classical instances such as Spanish vagabundo 'vagrant, tramp' > vagamundo after vagar 'to wander' + mundo 'world'.

As is clear from the preceding discussion, this kind of reasoning is intolerable, especially when it is not accompanied by a solid body of cultural and folkloristic knowledge to back it up. The book under review contains a few such cases. For instance, Manchu uju 'head' has, in theory, no cognates in other Tungusic languages (p. 76). Since body parts tend to be an important cultural phenomenon, it comes as no surprise that we find certain taboos attached to them. This general appreciation (which has a grain of truth to it), and the apparent "abnormality" of the etymological status of Manchu $u j u$, is enough to classify it as a taboo word. I agree with MK that this is dubious to say the least (it has been argued elsewhere that this word could actually be inherited, see J. A. Alonso de la Fuente, "Written Manchu uju 'head', Ural-Altaische Jahrbücher NF 24, 2011, pp. 204-226).

It goes without saying that the immense majority of instances presented by MK in this book are far less polemic. In this regard, MK's discussion is always balanced and very informative. Furthermore, there are cases that could actually be accounted for as genuine instances of taboo. The most telling example is the word for the sun, 
discussed by MK in pp. 70-71, for which there are two terms in Tungusic, namely *sïgoon and *dilacaa. These are apparently in complementary distribution, and therefore they are commonly used as a lexical isogloss to distinguish between Northern and Southern Tungusic languages (see i.a. J. Benzing, Die tungusischen Sprachen. Versuch einer vergleichenden Grammatik, Wiesbaden 1956, p. 11).

This work mainly deals with the lexicon of the Northern Tungusic languages, leaving aside the taboo vocabulary of Southern Tungusic and Manchu (as for the latter, there are copious references on the topic in Chinese and Japanese; note that it traditionally is assumed that the Southern Tungusic populations borrowed many cultural traits involving taboo from the Chinese). A direct consequence of this limitation is that many interesting words have been left out, even those which could have shed some light on certain Northern Tungusic items. For the sake of illustration, I will mention the enigmatic Eastern Ewenki word sorki 'sash, girdle (made of musk-deer leather and used during the menstrual cycle to protect against evil spirits)'. It is documented only in the Bitim dialect by E. I. Titov (see his Tungussko-russkij slovar', Irkutsk 1926, p. 133b <соркі>). The Ewenki form could be the re- sult of a very recent lexical dispersion whose point of departure must be Southern Tungusic. As a matter of fact, this term is well attested across all dialects of Udihe, Nanay and also Manchu (Literary Udihe soondo 'sin' = Kilen soron$d a$ - 'to consider as sinful', Manchu soroki = Ewenki sorki, see SSTMJa 2.113), where it is the common word for sin (and taboo!). The ritualistic origin of this word is preserved in the Manchu expression sorok $\hat{u}$ futa 'multicolored strings hung on a child's neck during a shamanistic rite' (J. Norman, A Concise Manchu-English Lexicon, Seattle / London 1978, p. 249a, and Corff, op. cit., vol. 1, p. 164 [66o-3]; cf. futa 'rope, line, string').

Another very interesting word is Ulcha <eniú $>\sim$ <yniú > 'sin' (cf. O.P. Sunik, Ul'čskij jazyk. Issledovanija i materialy, Leningrad 1985, p. 262 a s. v. änäwu id., note that $-w u$ is a derivative element, cf. SSTMJa $2.456 \mathrm{~b}$ where we find Ulcha ä̃ü- 'to sin'), related to Orok <ynnúri> = änäuri $\sim$ ännäwri 'sin' and <ynnáuri kucihá> = †ännäwri kucigä 'a knife to the handle of which the hair of the bear's sex organ is glued [a taboo knife)' (see i.a. SSTMJa 456b; for both Ulcha and Orok, see new materials in A. Majewicz et al. [eds.], The Collected Works of Bronistaw Piłsudski, vol. IV: Materials for the Study of Tungusic Languages and 
Folklore, Berlin 2011, pp. 524-525, $808,938)$. If we assume that there is no coincidence in that ännäwri belongs in a noun phrase with kucigä 'knife', then it is very tempting to link these words with Northern Tungusic *änä+kii 'sheath, scabbard' (> East Ewenki änäkii(ptun) and $\ddot{a} n \ddot{a}$-lää- 'to put in the sheath', Hailar Solon änixii, Literary Ewen \& Arman äñki, Negidal änäxii änäkii id., see SSMTJa 2.455a). The connection, however, sounds admittedly rather cumbersome, as the rationale behind it, or put another way, the cultural explanation for the taboo, remains obscure (it is clear here that the ritualistic nature of the knife plays an important role).

The inclusion of these and other words could have easily doubled the scope of the book. It could also have been very interesting to inspect original texts in order to check whether difficult items could actually be accounted for as the result of, or at least linked to, the phenomenon of taboo. However, there is always time for this kind of desiderata to be accomplished in the future.

In the theoretical section, MK seeks to reconcile the traditional position, supported by W. Havers and others, with more recent approaches, such as those defended in the unpublished dissertation of M. Crombach. MK convincingly argues that both trends pay too much attention to internal processes (metaphor, litotes, paraphrase, imitative words, etc.), whereas they ignore altogether the role played by external factors, such as lexical borrowing, e.g. Khingan Ewenki nukun 'vulva' $\leftarrow$ Mongolic nüken 'hole' (p. 33) or Manegir Solon גavu 'tiger' $\leftarrow$ Chinese lăo[dà] 'old [in a reverential way]' (p. 55). It is legitimate to wonder how many similar cases may be identified in the materials collected by K. A. Novikova ("Inojazyčnye èlementy v tungusoman'čžurskoj leksike, otnosjaščejsja $\mathrm{k}$ životnomu miru", in V.I. Cincius [ed.], Očerki sravnitel'noj leksikologii altajskix jazykov, Leningrad 1972, pp. 104-150).

All in all, this is a very valuable contribution to the study of Tungusic linguistics and culture. It makes available the personal thoughts of two important figures, namely Doerfer and Shirokogoroff, to which otherwise it would be very difficult to gain access. There is little doubt that the book will stimulate further discussion on the specifics of various items. There are some minor questions which in other circumstances would deserve further comment (e.g. vowel length in Manchu, internal classification of certain "dialects", etc.), but these contribute nothing to the topic of the book. Last but not least, note that the work has been recently up- 
Johanna Laakso

dated with the publication of addi- ten", Studia Linguistica Universitional materials mainly referring to tatis Iagellonicae Cracoviensis 130, animal taboos (M. Knüppel, "Nach- 2013, pp. 187-190).

schrift zu der Arbeit Sprachtabus in tungusischen Sprachen un Dialek-

José Andrés Alonso de la Fuente 